\title{
Hubungan Kegiatan Workshop Design Thinking Dengan Sikap Peserta Terhadap Kewirausahaan
}

\author{
Sherly Amelia, Hanny Hafiar, Heru Ryanto Budiana \\ sherlyamaliamoy@gmail.com, hannyhafiar@gmail.com, heru.prodihumas@unpad.ac.id \\ Fakultas Ilmu Komunikasi, Universitas Padjadjaran
}

\section{Correlations Between Workshop Design Thinking Perception And Participants Attitude Toward Entrepreneurship}

\begin{abstract}
The workshop was organized by West Java's Industry and Trade Service (Disperindag) in collaboration with Universitas Padjadjaran with purpose to produce new entrepreneurs. This research aims to discover the extent of the correlation between the workshop and the participants attitude toward entrepreneurship. Theory used in this research is ELM Theory by Richard E. Petty and John T. Cacioppo. This study uses quantitative method. Researcher used Random Sampling, in the population of the participants from the Batch 27 and 28, resulting 65 samples. Based on the recapitulation of the result of correlation and discussion, the result of this research showed that there was a significant correlation between the perception of workshop and the participants attitude toward entrepreneurship. The result indicates that the programs of this workshop significantly affected participant's will to start becoming entrepreneurs.
\end{abstract}

Keywords: training, entrepreneur, workshop design thinking, business

Received date: 29 November 2017

Article Info

Revised date: 3 April 2018

Accepted date: 4 Mei 2018

\section{PENDAHULUAN}

Pemerintah Provinsi Jawa Barat berupaya secara bertahap mewujudkan kesejahteran masyarakat melalui program dan kegiatan yang langsung dapat dirasakan manfaatnya oleh semua pihak. Hal ini berdasarkan visi pemerintah yang tercantum dalam Rencana Pembangunan Jangka Panjang Daerah (RPJMD) tahun 2013 - 2018 "Jawa barat Maju dan Sejahtera Untuk Semua” yang mengamanatkan penciptaan 100.000 wirausaha baru. Penciptaan wirausaha baru bertujuan untuk mewujudkan Sumber Daya Manusia berkualitas, serta menambah jumlah pengusaha Jawa Barat yang tangguh dan mandiri. Hal ini merupakan bagian dari kegiatan peningkatan kualitas hidup masyarakat, mengacu pada pendapat bahwa peningkatan kualitas hidup dapat dilakukan dengan berbagai aktivitas sehingga mampu menciptakan kemandirian (Yanto, Rodiah, \& Lusiana, 2016).

Peningkatan kualitas hidup masyarakat, dapat diupayakan melalui perbaikan tingkat kesejahteraan secara ekonomi. Kesejahteraan masyarakat ini merupakan salah satu tujuan pembangunan bangsa yang bisa dilakukan melalui dimensi pendidikan. Fattah Nanang (2012) mengemukakan pencapaian pembangunan dalam dimensi ekonomi, melalui aspek pendidikan diharapkan akan menghasilkan manusia yang handal sebagai penggerak pembangunan nasional yang mampu berdaya saing dalam memasuki persaingan bangsa di era globa (Giarti \& Astuti, 2016). Sehingga untuk mendukung program pemerintah Jawa Barat, Disperindag Jabar (Dinas Perindustrian dan Perdagangan Jawa Barat) mencanangkan program wirausaha yang berbentuk pelatihan. Tujuan dari pelatihan ini adalah untuk menumbuhkan kegiatan positif yang mendorong masyarakat, terutama di Jawa Barat untuk membentuk diri menjadi wirausahawan yang lebih baik. 
Pelatihan Wirausaha Baru (WUB) telah memasuki tahun ketiganya, dan pada tahun ini Unpad mengambil bagian sebagai salah satu stakeholder untuk menyediakan konten pembelajaran. Pelatihan pencetakan wirausaha baru ini oleh Unpad diberi judul "Workshop Design Thinking for Start-Up Business Development", dalam pencerminan konten dan bentuk pengajaran.

Pelatihan ini telah berjalan dimulai dari bulan Juli hingga November 2016. Hampir setiap minggu selama 5 hari diadakan pelatihan bagi para peserta yang telah dibagi per angkatan untuk mendapatkan ilmu serta pengetahuan baru dan juga berbagi pengetahuan tentang kewirausahaan. Antusiasme peserta yang mengikuti kegiatan ini pun tidak hanya bagi yang baru ingin memulai berwirausaha, tetapi juga yang telah memliki usaha namun ingin menambah pengetahuan dalam memperluas usaha miliknya tersebut. Pelatihan ini akan diselenggarakan hingga akhir bulan November 2016.

Unpad sebagai salah satu stakeholder mengumpulkan 6.000 peserta yang akan mengikuti pelatihan program Workshop setiap minggunya dan dibagi per 2 angkatan. Masing-masing angkatan dibagi menjadi 100 peserta per angkatan per minggunya. Pendaftarannya masih dilakukan dengan sistem yang bebas, namun mereka menyatakan untuk ke depannya akan berusaha memperbaiki sistem itu dengan melihat proporsi latar belakang pendaftar.

Pelatihan ini diharapkan dapat menjadi program berkelanjutan jangka panjang yang dapat dilaksanakan setiap tahunnya. Selain untuk menambah life skill dalam bidang kewirausahaan, tentu dengan munculnya berbagai wirausaha yang semakin banyak dapat memperluas ruang lowongan pekerjaan bagi masyarakat di daerah sekitar mereka atau bahkan dapat terus berkembang sebagai produk asli hasil dari rakyat Indonesia.

Berdasarkan wawancara yang dilakukan sebagai pra-riset, tujuan utama dari program Workshop oleh Unpad ini adalah untuk memberikan fundamental-fundamental kewirausahaan dalam membentuk pelaku-pelaku usaha baru. Kegiatan pelatihan ini menggunakan design thinking, yang dibagi mulai dari cara observasi yang benar, cara mensintesis yang benar, prototyping, pembuatan pembukuan, HPP, dan business model. Di balik semua itu, yang menjadi intinya bukanlah keterampilan teknis, melainkan penyadaran kepada peserta untuk memmiliki paradigma yang benar, seperti yang diajarkan dalam pelatihan. Unpad percaya bahwa yang membuat suatu komunitas maju adalah dengan adanya berbagi pengetahuan dan pengalaman, keterbukaan untuk bekerjasama, dan komunikasi yang baik. Sehingga mampu melahirkan kemandirian, mampu bergerak maju untuk kegiatan wirausahanya. Semakin luas jaringannya, maka semakin terbuka pula kesempatan untuk menjadi lebih baik.

Berdasarkan Storytell-Design Thinking from PRSA, Design Thinking adalah suatu keadaan pemikiran. Dinyatakan bahwa:

"It's a human-centric, holistic approach to problem solving and business thinking that employs empathy, ideation, prototyping and experimentation to solve real-world issues. For organizations seeped in this approach, Design Thinking works horizontally across an organization to tear down silos, improve communications, and deliver new insights".

Kegiatan ini juga merupakan kegiatan yang dilaksanakan atas kerjasama dengan berbagai pihak. Pada initinya mengacu pada hasil riset dinyatakan bahwa: "ada beberapa hal yang bisa membuat kemitraan berjalan sukses adalah memperlakukan pihak yang bermitra sebagai kesempatan untuk mengizinkan orang-orang dengan latarbelakang yang berbeda untuk belajar satu sama lain" (Nassaluka, Hafiar, \& Priyatna, 2016). 
Melalui program pelatihan ini ini, peserta yang baru ingin menjadi seorang wirausaha diajarkan untuk dapat menumbuhkan minat akan kewirausahaan. Lalu bagi para peserta yang telah memiliki bisnis, dengan mengikuti pelatihan ini tentu akan menambah pengetahuan dalam memajukan bisnis mereka. Baik para pengajar dan pesan yang disampaikan ditujukan agar peserta dapat menerima dan memahami serta menerapkannya dalam kehidupan seharihari sebagai seorang wirausaha. Salah satu kegiatan yang diberikan dalam pelatihan ini adalah contoh praktik, termasuk bersikap mandiri, menjadi pimpinan bagi diri sendiri. Cara alamiah mempelajari kepemimpinan adalah dengan melakukannya dalam kerja dengan praktik (Artawan, Shintadewi, \& Budiana, 2016).

Cakupan sasaran dari kegiatan ini cukup luas. Kualifikasi yang diberikan oleh Disperindag Jabar sebagai penyelenggara program Workshop adalah laki-laki dan perempuan yang berdomisili di Jawa Barat, berumur 18-65 tahun, dengan latar belakang pendidikan dari SD, SMP, SMA, S1, S2, S3. Narasumber yang diwawancarai sebagai pra-riset ini pun mengakui bahwa cakupan yang sangat luas ini cukup menyulitkan Unpad sebagai penyedia konten, sekaligus merupakan tantangan tersendiri bagi pengajar dan penyedia materi.

Menurut penuturan salah seorang staff pengajar pelatihan pada saat wawancara, Arina Qonita, dijelaskan bahwa:

“...iya, contohnya aja kemarin ya. Aku diprotes sama beberapa peserta kalo aku terlalu sering memakai bahasa Inggris dalam penyampaian materi. Sebenernya kan posted pada design thinking ini asalnya dari luar negeri, kita pun belajarnya pake bahasa Inggris, jadi ada beberapa kata yang ketika disampaikan kita agak bingung untuk menjelaskannya agar mereka menerima pesannya sesuai yang kita maksud. Ada juga yang bilang ketika aku menyampaikan materinya dan menyebut satu merek/produk sebagai contoh, dianggapnya aku sedang promosi".

Presentasi dan penjelasan Design Thinking diberikan sebagai materi pembuka dari kegiatan Workshop. Cara penyampaian komunikator yang kurang jelas serta penjelasan yang terkadang rumit untuk dimengerti hanya dengan sekali penjelasan menyebabkan adanya kesenjangan dalam penyampaian pesan. Sehingga cara penyampaian, komunikator dan pesan yang disampaikan ingin diteliti oleh peneliti untuk melihat bagaimana komunikasi persuasif tersebut mampu berjalan dalam pelatihan ini.

Namun, realita yang ditemukan di lapangan tidak sesuai dengan tujuan yang diinginkan. Banyak peserta yang mengeluhkan beberapa hal dalam pemberian materi tersebut, mengenai ajakan kewirausahaan yang dianggap masih kurang, kesalahan pandangan bahwa pengajar melakukan promosi untuk suatu produk dan juga banyak yang masih kurang mengerti beberapa kata/ istilah tertentu walaupun telah dijelaskan dalam tulisan pada slide presentasi dan juga dijelaskan secara lisan.

Setelah melakukan pra riset ternyata terdapat kesenjangan antara tujuan yang ingin dicapai dengan penerimaan peserta dalam penyampaian materi selama pelatihan berlangsung. Berdasarkan fakta dan permasalahan di atas, peneliti tertarik untuk meneliti hubungan antara penyampaian pesan oleh komunikator dan metode yang digunakan, serta bagaimana sikap peserta atas pelatihan ini agar mampu menumbuhkan minat menjadi seorang wirausaha dan juga mampu mengaplikasikannya pada kehidupan nyata.

Teori sebagai landasan dari penelitian ini adalah Elaboration Likelihood Model of Persuasion oleh Richard E. Petty dan John T. Cacioppo (1986). Teori ini dipilih berdasarkan pada program pelatihan yang dilaksanakan oleh Unpad sebagai penyedia materi pembelajaran yang bertujuan untuk menumbuhkan minat peserta yang baru berkeinginan untuk menjadi seorang wirausaha. Selama pelatihan ini, pemberian materi, kegiatan sharing antara pengajar 
dan peserta ataupun sesama peserta dilakukan tanpa unsur pemaksaan melainkan dengan bentuk mengajak untuk membentuk sikap akhir yaitu menjadi seorang wirausaha.

Asumsi dasar dari teori ini adalah bahwa seseorang dapat memroses pesan persuasif dengan cara yang berbeda. Pada suatu situasi seseorang menilai sebuah pesan secara mendalam, hati-hati dan dengan pemikiran yang kritis, namun pada situasi lain dapat menilai pesan sambil lalu saja tanpa mempertimbangkan argumen yang mendasari isi pesan tersebut (Griffin dalam Venus, 2009:121).

Menurut Petty dan Cacioppo, sewaktu individu dihadapkan pada pesan persuasif maka ia akan memikirkan pesan itu, memikirkan argumentasi apa yang terkandung di dalamnya dan argumentasi apa yang tidak. Pemikiran-pemikiran (elaboration) inilah yang membawa kepada penerimaan atau penolakan pesan yang disampaikan, bukan pesan itu sendiri. Akan tetapi pemikiran yang dilakukan bukanlah pemikiran yang dalam sebagaimana yang terjadi sewaktu berpikir menghadapi persoalan yang berat. Sejauh mana seseorang akan berpikir tergantung pada seberapa penting dan seberapa relevannya pesan tersebut. Jika pesan yang disampaikan itu sangat penting dan relevan, barulah akan dipikirkan secara lebih hatihati dan mendalam (Azwar, 2011:67-68).

"The Elaboration Likelihood Model brings together several of the elements we have looked at above (attitudes, behavior, message compounds). This cognitive model of persuasion emphasizes the thoughts and ideas that occur to people as they attend to persuasive communication”. (Petty \& Cacioppo dalam Baldwin, 2004:151-152)

Menurut Elaboration Likelihood Model (ELM), ada dua jalur proses yang dapat dipilih oleh individu guna memikirkan pesan yang disampaikan. Pemilihan ini didasarkan pada urgensi dan relevansi pesan. Proses pertama adalah apabila individu memberikan perhatian penuh terhadap pesan dan argumentasinya dan karenanya ia menerima persuasi lewat jalur sentral (central route). Lewat jalur sentral akan terjadi pemikiran yang hati-hati dan mendalam, penuh pertimbangan mengenai argumentasi yang dapat disimpulkan dari pesan yang disampaikan. Sejauh mana argumentasi yang ada dapat diterima dengan meyakinkan sejauh itu pula perubahan sikap seseorang akan terjadi. Sebaliknya, apabila argumentasi yang terkandung dalam pesan tidak dapat meyakinkan, maka perubahan sikap tidak akan terjadi (Azwar, 2011:68).

Jalur kedua adalah jalur periferal (peripheral route). Tanpa pemikiran yang mendalam, bahkan hampir secara otomatis, persuasi mendapat respons langsung dari individu. Respons lewat jalur ini dimungkinkan apabila kunci persuasi (persuasion cues) merupakan informasi yang ada hubungannya dengan keahlian atau status pelaku persuasi atau berupa penyajian suatu komunikasi dua arah yang tampak lebih seimbang dan tidak memihak. Jalur periferal juga cenderung dilalui apabila target atau subjek persuasi dalam keadaan terpecah konsentrasinya sehingga tidak dapat menaruh perhatian penuh dan tidak dapat melakukan analisis mendalam terhadap isi pesan yang disampaikan. (Azwar, 2011:68)

Berdasarkan latar belakang yang telah peneliti uraikan, maka rumusan masalah yang dapat dikemukakan peneliti adalah "Sejauh mana hubungan antara Workshop Design Thinking for Start-Up Business Development oleh Universitas Padjadjaran dengan sikap peserta terhadap kewirausahaan?".

\section{METODE PENELITIAN}

Metode yang peneliti gunakan dalam penelitian ini adalah metode korelasional. Metode korelasional meneliti hubungan diantara variabel-variabel. Metode korelasi bertujuan 
meneliti sejauh mana variasi pada satu faktor berkaitan dengan variasi pada faktor lain. Kalau dua variabel saja yang kita hubungkan, korelasinya disebut korelasi sederhana (simple correlation). Lebih dari dua, kita menggunakan korelasi ganda (multiple correlation) (Rakhmat, 2009:27).

Teknik yang digunakan pada penelitian ini adalah teknik Probability Sampling dengan jenis Simple Random Sampling. Probability Sampling, yaitu teknik pengambilan sampel yang memberikan peluang yang sama bagi setiap unsur (anggota) populasi untuk dipilih menjadi anggota sampel. Simple Random Sampling adalah pengambilan anggota sampel dari populasi dilakukan secara acak tanpa memperhatikan strata yang ada dalam penelitian itu. (Sugiyono, 2009:122-123).

Penelitian korelasional ini berkaitan dengan penggunaan metode korelasional untuk meneliti hubungan antara pelatihan Workshop Design Thinking for Start-Up Business Development oleh Unpad sebagai penyedia konten dan penyampai konten (variabel $\mathrm{X}$ ) terhadap perubahan sikap peserta mengenai kewirausahaan (variabel Y), berdasarkan teori Elaboration Likelihood Model (ELM) yang mana memiliki dua jalur, yaitu jalur sentral (central route) dan jalur periferal (peripheral route).

Program pelatihan ini yang terdiri dari materi pelatihan, kredibilitas pelatih, dan metode pelatihan adalah yang akan diproses oleh peserta baik melalui jalur sentral ataupun jalur periferal, yang akan memunculkan dan menunjukkan sikap peserta terhadap kewirausahaan yang dilihat berdasarkan aspek kognitif, afektif, dan konatif. Masing-masing dari program dan sikap peserta yang akan muncul merupakan hasil korelasi dari penelitian ini dan akan menjadi hasil akhir untuk dibahas.

Populasi dari penelitian ini adalah angkatan 27 dan angkatan 28 yang berjumlah 200 orang, yang mana pelatihan ini dilaksanakan pada 7-11 November 2016 yang bertempat di Hotel Bumi Kitri, Bandung. Alasan peneliti memilih angkatan 27 dan 28 sebagai populasi dari penelitian ini adalah karena pengajar pada pelatihan ini menyatakan bahwa peserta angkatan 27 dan 28 merupakan peserta yang banyak memberikan aspirasi berupa kritik dan saran atas kegiatan yang berlangsung. Sehingga peneliti memilih 2 angkatan tersebut sebagai populasi pada penelitian ini. Berdasarkan perhitungan, maka sampel yang diperlukan dalam penelitian ini adalah 65 orang peserta dari 200 orang per 2 angkatan.

Validitas penelitian diklasifikasikan menjadi validitas internal dan validitas eksternal. Validitas internal berkaitan dengan keyakinan peneliti tentang kesahihan hasil penelitian, sedangkan validitas eksternal berkaitan dengan tingkat generalisasi hasil penelitian yang diperoleh. Validitas hasil penelitian berada pada suatu garis kontinum yang terbentang dari mulai yang sangat tidak valid sampai dengan yang sangat valid (Furqon dalam Taniredja, 2012:42).

Pengujian validitas instrumen penelitian menggunakan koefisien korelasi Rank Spearman untuk mengukur tingkat atau eratnya hubungan antara dua variabel yaitu variabel bebas dan terikat, yang berskala ordinal, mengetahui tingkat kecocokan dari dua variabel terhadap grup yang sama, mendapatkan validitas empiris.

Reliabilitas menunjuk pada satu pengertian bahwa sesuatu instrumen cukup dapat dipercaya untuk digunakan sebagai alat pengumpul data karena instrumen tersebut sudah baik. Instrumen yang baik tidak akan bersifat tendensius mengarahkan responden untuk memilih jawaban-jawaban tertentu. Instrumen yang sudah dapat dipercaya, yang reliabel akan dapat menghasilkan data yang dapat dipercaya juga. Apabila datanya memang benar sesuai dengan kenyataan, maka berapa kali pun diambil, akan tetap sama. reliabilitas menunjuk pada suatu tingkat keterandalan sesuatu. Reliabel artinya, dapat dipercaya, jadi dapat diandalkan (Arikunto dalam Taniredjo, 2012:43).

Analisis deskriptif adalah statistik yang digunakan untuk menganalisis data dengan cara mendeskripsikan atau menggambarkan data yang telah terkumpul sebagaimana adanya 
tanpa bermaksud membuat kesimpulan yang berlaku untuk umum atau generalisasi. Penelitian yang dilakukan pada populasi (tanpa diambil sampelnya) jelas akan menggunakan statistik deskriptif dalam analisisnya. Tetapi bila penelitian dilakukan pada sampel, maka analisisnya dapat menggunakan statistik deskriptif maupun inferensial. Statistik deskriptif dapat digunakan bila peneliti hanya ingin mendeskripsikan data sampel dan tidak ingin membuat kesimpulan yang berlaku untuk populasi tempat sampel diambil (Sugiyono, 2013:199-200).

Statistik inferensial (sering juga disebut statistik induktif dan statistik probabilitas) adalah teknik statistik yang digunakan untuk menganalisis data sampel dan hasilnya diberlakukan untuk populasi. Statistik ini akan cocok digunakan bila sampel diambil dari populasi yang jelas, dan teknik pengambilan sampel dari populasi ini dilakukan secara random (Sugiyono:2013:201).

\section{HASIL DAN PEMBAHASAN}

Penelitian ini membahas mengenai Pelatihan Workshop Design Thinking for Start-Up Business Development oleh Universitas Padjadjaran yang difokuskan pada angkatan 27 dan 28, yang diselenggarakan di Hotel Bumi Kitri, Bandung. Kegiatan ini merupakan bentuk kerjasama Universitas Padjadjaran dengan Disperindag Jabar untuk mendukung program pemerintah Jawa Barat Disperindag Jabar (Dinas Perindustrian dan Perdagangan Jawa Barat) dalam mencanangkan program wirausaha yang berbentuk pelatihan.

Penelitian ini menggunakan teori ELM (Elaboration Likelihood Model) oleh Richard E. Petty dan John T. Cacioppo. Teori ini dipilih berdasarkan pada program pelatihan yang dilaksanakan oleh Unpad sebagai penyedia materi pembelajaran yang bertujuan untuk menumbuhkan minat peserta yang baru berkeinginan untuk menjadi seorang wirausaha. Untuk menjadi seorang wirausahawan, dibutuhkan karakter khusus yang dapat dibentuk melalui pendidikan. Pendidikan karakter bisa ditempuh melalui pendidikan formal dan informal (Wanabuliandari \& Ardianti, 2018). Selama pelatihan ini, pemberian materi, kegiatan sharing antara pengajar dan peserta ataupun sesama peserta tidak dilakukan tanpa unsur pemaksaan melainkan dengan bentuk mengajak untuk membentuk sikap akhir yaitu menjadi seorang wirausaha.

Berdasarkan hal tersebut maka penelitian ini sejalan dengan teori Elaboration Likelihood Model (ELM). Asumsi dasar dari teori ini adalah bahwa orang dapat memproses pesan persuasif dengan cara yang berbeda. Pada suatu situasi kita menilai sebuah pesan secara mendalam, hati-hati dan dengan pemikiran yang kritis, namun pada situasi lain kita menilai pesan sambil lalu saja tanpa mempertimbangkan argumen yang mendasari isi pesan tersebut. (Griffin dalam Venus, 2009:121).

Menurut Petty dan Cacioppo, sewaktu individu dihadapkan pada pesan persuasif maka ia akan memikirkan pesan itu, memikirkan argumentasi apa yang terkandung di dalamnya dan argumentasi apa yang tidak. Pemikiran-pemikiran (elaboration) inilah yang membawa kepada penerimaan atau penolakan pesan yang disampaikan, bukan pesan itu sendiri. Akan tetapi pemikiran yang dilakukan bukanlah pemikiran yang dalam sebagaimana yang terjadi sewaktu kita berpikir menghadapi persoalan yang berat. Sejauh mana kita akan berpikir tergantung pada seberapa penting dan seberapa relevannya pesan tersebut bagi kita. Kalau memang pesan yang disampaikan itu sangat penting dan relevan bagi kita, barulah kita akan berpikir secara lebih hati-hati dan mendalam (Azwar, 2011:67-68).

Penelitian korelasional ini berkaitan dengan penggunaan metode korelasional untuk meneliti hubungan antara pelatihan Workshop Design Thinking for Start-Up Business Development oleh Unpad sebagai penyedia konten dan penyampai konten (variabel X) terhadap perubahan sikap peserta mengenai kewirausahaan (variabel Y), berdasarkan teori 
Hubungan Kegiatan Workshop Design Thinking Dengan Sikap Peserta Terhadap Kewirausahaan (Sherly Amelia, Hanny Hafiar, Heru Ryanto Budiana)

Elaboration Likelihood Model (ELM) yang mana memiliki dua jalur, yaitu jalur sentral (central route) dan jalur periferal (peripheral route).

Tabel 1.

Hubungan Variabel/Sub Variabel Penelitian

\begin{tabular}{ccccccc}
\hline Korelasi & Rs & Kriteria & t hitung & t tabel & Keputusan & Kesimpulan \\
\hline $\mathrm{X}-\mathrm{Y}$ & 0,638 & Cukup Berarti & 7,947 & 1,997 & $\mathrm{H}_{0}$ Ditolak & Terdapat Hubungan \\
\hline $\mathrm{X} 1-\mathrm{Y} 1$ & 0,402 & Cukup Berati & 4,211 & 1,997 & $\mathrm{H}_{0}$ Ditolak & Terdapat Hubungan \\
\hline $\mathrm{X} 1-\mathrm{Y} 2$ & 0,358 & Rendah tapi Pasti & 3,678 & 1,997 & $\mathrm{H}_{0}$ Ditolak & Terdapat Hubungan \\
\hline $\mathrm{X} 1-\mathrm{Y} 3$ & 0,349 & Rendah tapi Pasti & 3,572 & 1,997 & $\mathrm{H}_{0}$ Ditolak & Terdapat Hubungan \\
\hline $\mathrm{X} 2-\mathrm{Y} 1$ & 0,489 & Cukup Berarti & 5,377 & 1,997 & $\mathrm{H}_{0}$ Ditolak & Terdapat Hubungan \\
\hline $\mathrm{X} 2-\mathrm{Y} 2$ & 0,412 & Cukup Berati & 4,337 & 1,997 & $\mathrm{H}_{0}$ Ditolak & Terdapat Hubungan \\
\hline $\mathrm{X} 2-\mathrm{Y} 3$ & 0,417 & Cukup Berarti & 4,401 & 1,997 & $\mathrm{H}_{0}$ Ditolak & Terdapat Hubungan \\
\hline $\mathrm{X} 3-\mathrm{Y} 1$ & 0,614 & Cukup Berarti & 7,461 & 1,997 & $\mathrm{H}_{0}$ Ditolak & Terdapat Hubungan \\
$\mathrm{X} 3-\mathrm{Y} 2$ & 0,403 & Cukup Berarti & 4,224 & 1,997 & $\mathrm{H}_{0}$ Ditolak & Terdapat Hubungan \\
\hline $\mathrm{X} 3-\mathrm{Y} 3$ & 0,306 & Rendah tapi Pasti & 3,083 & 1,997 & $\mathrm{H}_{0}$ Ditolak & Terdapat Hubungan \\
\hline \multicolumn{2}{c}{ Sumber: Pengolahan Data 2017 } & & &
\end{tabular}

Secara keseluruhan, pelatihan Workshop Design Thinking for Start-Up Business Development memiliki hubungan yang cukup berarti terhadap sikap peserta terhadap kewirausahaan. Dapat disimpulkan pula bahwa kegiatan pelatihan yang berisikan materi Design Thinking ini merupakan kegiatan pengajaran yang mampu mengubah sikap peserta terhadap kewirasuahaan. Hal ini sejalan dengan hasil penelitian yang menyebutkan bahwa, materi pendidikan karakter dapat berpengaruh terhadap peningkatan perilaku (Gilang, Sihombing, \& Sari, 2018). Teori Elaboration Likelihood Model menjelaskan bahwa terdapat dua rute atau jalur yang ditempuh oleh tiap individu dalam memproses pesan. Pemrosesan pesan tersebut dapat mengubah sikap seseorang untuk jangka waktu yang lama, atau jangka yang lebih pendek, atau bahkan tidak sama sekali. Baik penggunaan jalur sentral ataupun jalur periferal memiliki pemrosesan masing-masing yang terjadi dalam diri individu. Seberapa besar perubahan atas pengaruh tersebut ditentukan oleh kemampuan dan keinginan peserta untuk mampu memproses informasi yang diberikan dan seberapa yakin mereka untuk menerima informasi tersebut dan menerapkannya dalam kehidupan sehari-hari.

Berdasarkan hasil tersebut dapat disimpulkan bahwa semua tergantung pada kemampuan dan motivasi individu untuk memproses yang didapatkan melalui jalur sentral atau hanya memandang kunci persuasi periferal saja. Melalui materi pelatihan yang masih sedikit diketahui dan merupakan ilmu baru menjadi nilai tambah dalam meningkatnya pemrosesan melalui jalur sentral dimana peserta menjadi ingin lebih tahu, walaupun masih kurang dalam menciptakan pemahaman dan keyakinan bagi peserta dikarenakan pemberian materi yang dirasa terlalu singkat. Kredibilitas pelatih dilihat pada hasil pembahasan akan mampu membentuk pemahaman dan kepercayaan peserta sebagai fundamental dalam berwirausaha. Dan melalui metode yang disusun dan dijalankan sedemikian rupa agar mudah disampaikan oleh pelatih dan dimengerti peserta dinilai dapat diterima untuk menciptakan pemahaman lebih terhadap materi pelatihan, yang akan berujung pada pemikiran melalui jalur sentral, ataupun periferal yang dimaksudkan menumbuhkan ketertarikan untuk memikirkan lebih dalam dan kembali pada jalur sentral.

Sedangkan pada aspek afektif yang mana berhubungan dengan kepercayaan peserta, apakah hal tersebut mendukung kepercayaan yang mereka miliki atau tidak akan mempengaruhi dan mendorong perasaan positif mereka terhadap kebutuhan akan diri sendiri atau kewirausahaan. Baik materi yang diberikan, kredibilitas pelatih, dan metode dalam pelatihan ini dinilai akan mampu mendukung kepercayaan yang dimiliki peserta mengenai perasaan mereka dalam menjalankan kewirausahaan. 
Kedua hal diatas akan mempengaruhi aspek konatif yang mana membentuk perilaku peserta tidak hanya dilihat secara langsung tetapi meliputi bentuk perilaku berupa pernyataan atau perkataan yang diucapkan oleh seseorang. Dari ketika variabel tersebut, masing-masing variabel memberikan kontribusi dalam mendukung kepercayaan peserta yang mana akan menambah perasaan suka terhadap kewirasuahaan. Idealnya, efektif atau tidaknya metode pelatihan yang diberikan harus disesuaikan dengan sikap pembelajaran peseta dan jenis pekerjaan yang mereka jalankan atau butuhkan. Agak berbeda dengan temuan ini, nampaknya apa yang disampaikan (Wibowo, 2015: 72) bahwa faktor lingkungan memegang peranan yang besar dalam menentukan kinerja seseorang dipertimbangkan.

\section{SIMPULAN DAN SARAN}

Berdasarkan hasil penelitian yang berjudul "Hubungan Persepsi Workshop Design Thinking for Start-Up Business Development oleh Universitas Padjadjaran dengan Sikap Peserta terhadap Kewirausahaan" yang diteliti, maka dapat ditarik simpulan sebagai berikut.

Materi pelatihan pada Workshop Design Thinking for Start-Up Business Development memiliki hubungan yang cukup berarti dengan komponen kognitif. Memiliki hubungan yang rendah tapi pasti dengan komponen afektif dan konatif. Materi pelatihan dinilai dapat mendukung keyakinan peserta sehingga cukup dapat menambah pemahaman. Materi pelatihan yang sesuai dengan urgensi dan relevansi peserta maka menimbulkan sikap positif dalam komponen kognitif.

Kredibilitas pelatih pada Workshop Design Thinking for Start-Up Business Development memiliki hubungan yang cukup berarti dengan komponen kognitif, afektif dan konatif. Kredibilitas pelatih yang menyampaikan informasi dinilai cukup dapat mempengaruhi keyakinan peserta terhadap kewirausahaan. Dengan keahlian, kepercayaan, dan daya tarik pelatih menimbulkan sikap positif peserta terhadap informasi kewirausahaan yang disampaikan.

Metode pelatihan pada Workshop Design Thinking for Start-Up Business Development memiliki hubungan yang cukup berarti dengan komponen kognitif dan afektif. Memiliki hubungan yang rendah tapi pasti dengan komponen konatif. Metode pelatihan sebagai cara penyampaian materi dinilai dapat mempengaruhi keyakinan peserta terhadap kewirausahaan. Dengan motivasi, gambaran, dan diskusi yang dilakukan peserta dan tutor pada pelatihan menimbulkan sikap positif peserta terhadap keyakinan informasi kewirausahaan yang disampaikan.

Berdasarkan hasil penelitian, maka peneliti mengajukan beberapa saran, yaitu: materi pelatihan Workshop Design Thinking for Start-Up Business Development oleh Universitas Padjadjaran disarankan untuk lebih memperhatikan istilah-istilah yang digunakan dan lebih baik disampaikan dengan memperbanyak penggunaan Bahasa Indonesia. Sasaran peserta diharapkan dapat lebih diperjelas lagi. Dengan rentang umur yang cukup luas, yaitu dari umur 25 tahun hingga 50 tahun, maka akan lebih baik jika pemberian pesan lebih disesuaikan dengan umur dan tingkat pendidikan penerima sehingga dapat menghindari pesan yang berlebih dan membuat peserta bosan.

Pemilihan narasumber ahli pada saat sesi success story disarankan merupakan pengusaha kecil menengah yang cakupan usahanya masih tidak terlalu besar. Sehingga peserta dapat memiliki gambaran memulai usaha dan pengembangan usahanya secara perlahan. Alternatif lainnya adalah dengan mengundang salah satu peserta yang terdahulu namun telah sukses untuk berbagi pengalaman, untuk memotivasi peserta karena masih terdapat hubungan emosional yang dapat dirasakan oleh peserta dan narasumber. Intensitas pelatihan perlu ditingkatkan, salah satunya dengan cara menambah jumlah tutor dalam setiap pelatihan. 
Hubungan Kegiatan Workshop Design Thinking Dengan Sikap Peserta Terhadap Kewirausahaan

(Sherly Amelia, Hanny Hafiar, Heru Ryanto Budiana)

\section{DAFTAR PUSTAKA}

Artawan, G. A. W. M., Shintadewi, E. A., \& Budiana, H. R. (2016). Makna kegiatan unilever future leaders league bagi para peserta. Jurnal Profesi Humas, 1(1), 1-11.

Azwar, Saifuddin. 2013. Sikap Manusia. Yogyakarta: Pustaka Pelajar

Baldwin, John R. 2004. Communication Theories. United States of America: Pearson Education

Giarti, S., \& Astuti, S. (2016). Implementasi Tqm Melalui Pelatihan Model In House Training Untuk Meningkatkan Kompetensi Pedagogik Guru SD. Scholaria: Jurnal Pendidikan Dan Kebudayaan, 6(2), 80-91. Retrieved from http://ejournal.uksw.edu/scholaria/article/viewFile/231/209

Gilang, L., Sihombing, R. M., \& Sari, N. (2018). Pengaruh Konteks pada Ilustrasi Buku Pendidikan Karakter terhadap Perilaku Disiplin Anak Usia Dini. Scholaria: Jurnal Pendidikan dan Kebudayaan, 8(1), 41-50.

Nassaluka, E. U. R., Hafiar, H., \& Priyatna, C. C. (2016). Model Kemitraan PT. Holcim Indonesia Tbk. Jurnal Profesi Humas, 1(1), 22-34.

PWR New Media. 2-15. Design Thinking for Marketing Communications Professionals. Wilmette, Illionis.

Rakhmat, Jalaluddin. 2009. Metode Penelitian Komunikasi. Bandung: PT Remaja Rosdakarya

Sugiyono. 2013. Metode Penelitian Kuantitatif Kualitatif dan R\&D. Bandung: Alfabeta

Taniredja, Tukiran. 2012. Penelitian Kuantitatif (Sebuah Pengantar). Bandung: Alfabeta

Venus, Antar. 2009. Manajemen Kampanye. Bandung: Simbiosa Rekatama Media

Wibowo, D. H. (2015). Motivasi Berprestasi Dalam Kaitannya Dengan Kinerja Guru. Scholaria: Jurnal Pendidikan dan Kebudayaan, 5(3), 65-74.

Wanabuliandari, S., \& Ardianti, S. D. (2018). Pengaruh Modul E- Jas Edutainment terhadap Karakter Peduli Lingkungan dan Tanggung Jawab. Scholaria: Jurnal Pendidikan Dan Kebudayaan, 8(1), 70-79.

Yanto, A., Rodiah, S., \& Lusiana, E. (2016). Model aktivitas gerakan literasi berbasis komunitas di sudut baca Soreang. Jurnal Kajian Informasi \& Perpustakaan, 2(1), $107-118$ 